\title{
Mechanical properties of mammalian single smooth muscle cells \\ II. Evaluation of a modified technique for attachment of cells to the measurement apparatus
}

\author{
J. J. GLERUM* and R. VAN MASTRIGT \\ Departments of Urology and Biomedical Physics and Technology, Erasmus University Rotterdam. The Netherlands.
}

Received 27 June 1989; accepted 18 April 1990

\begin{abstract}
Summary
A method is described for attaching isolated single smooth muscle cells to an apparatus designed for measuring the longitudinal forces developed passively and actively by the cell upon straining, electrical or pharmacological stimulation.

Primary attachment of the cell is based on its natural negative surface charge in combination with a positive surface charge on the micro-tools used for attaching. Definite attachment is obtained by a knotting technique. Results show that this method of attachment is reliable and strong enough to withhold forces exceeding those necessary to break or tear the cell.

Although this method allows relatively short cells to be attached ( $\mathrm{L}>80 \mu \mathrm{m}$.) alternative methods e.g. glueing, are necessary to attach the shortest smooth muscle cells.
\end{abstract}

\section{Introduction}

In the field of muscle contractility research, especially on smooth muscle, there is general agreement on the value and necessity of single cell contractility measurements (Fay et al., 1976, Glerum et al., 1987). Amongst the essentials needed for such measurements are methods for single cell isolation, a sensitive microforce transducer and a method for cell attachment. In the first paper on single cell measurements Fay (1977) introduced a method for knotting a single cell to micro-tools. A number of other methods of smooth muscle cell attachment have been published, e.g. a method of sucking the cell ends into micro-pipettes (Ishii \& Takahashi, 1982). This introduces the problem of maintaining compliance and stability in the measurement apparatus as the necessary vacuum has to be created, transduced, maintained and controlled separately from the actual transducer. In the quoted references it was shown that this problem can be solved by optically measuring the degree of bending of the tip of the micropipette the cell is sucked into, but due to a relatively long optical path, the long term stability of such a measurement method is poor and calibration of each new pipette tip is necessary (Ishii, 1988, personal communication). Another disadvantage of methods involving the measurement of the bending of a pipette tip, is the non-optimal axial pull on the smooth muscle cell. The cell either has to bend sharply at both ends, as in Ishii's method (Ishii et al., 1988), or has to be folded in the middle as in the methods of Tung (1986) or Van Dijk-Looyaard (Van Dijk et al., 1984). In this last method cells are clamped to the bottom of the cell incubator so that the stability of the attachment depends on the friction between the cell and the bottom of the incubator and also between the cell and the micro-tips. As both levels of friction are generally low, slipping of the attachment does occur in this method.

The best way of attaching a muscle cell would simply be to glue it to the micro-tools in use, but except for the use of fibrin glue (Copelas et al., 1987), almost all attempts to do so have failed thus far. The major problem of glueing, besides finding a bio-compatible glue, lies in the far more difficult control of glue solutions in micropipettes and injectors and the controlling and positioning of a significantly increased number of micro-manipulators.

In this article we report our experiences with the knotting technique as originally published by Fay (1977) and described in detail by Warshaw \& Fay (1983), applied to pig urinary bladder and human a terme pregnant uterus smooth muscle cells. Several fundamental changes in this method were necessary, which led to significant improvements. 


\section{Materials and methods}

Single smooth muscle cells from pig urinary bladders were isolated by enzymatic digestion of strips of bladder tissue collected at the local slaughterhouse. Single smooth muscle cells from a terme human uteruses were obtained likewise from biopsies excised at Caesarean sections. Both procedures were carried out as described previously (Glerum et al., 1987), except for an additional overnight incubation in collagenase at $4^{\circ} \mathrm{C}$ for both types of tissue and an additional trypsinisation of the pig bladder tissue.

To be able to select vital cells during the experiments a Fluorecine Di-Acetate vital staining technique was used: After isolation the cells were incubated in a freshly prepared diluted FDA. solution for 15 min., next the FDA. was removed by centrifugation and the cells were resuspended in $2 \mathrm{ml}$ of Krebs-Hepes buffer and $1 \mathrm{ml}$ of MEM./10\% FCS. This cell suspension was immediately poured into the cell incubator, the vital cells thus showing a clear green intracellular fluorescence. Detailed description of the procedure is available on request.

During experiments the cells were incubated in a specially constructed cell incubator with a bottom of optical glass mounted on a Zeiss inverted microscope equipped with phase contrast and incident light fluorescence optics. Conditions of incubation were kept at temperature $37^{\circ} \mathrm{C}, \mathrm{P}_{\mathrm{O}_{2}} 150 \mathrm{~mm} \mathrm{Hg}$ and $\mathrm{P}_{\mathrm{CO}_{2}} 38 \mathrm{~mm} \mathrm{Hg}$ approximately, thus resulting in $\mathrm{pH} 7.35$ (Glerum et al., 1987). Fluid evaporation was prevented with a thin layer of Klearol (Van Dijk et al., 1984).
Cell attachment micro-tools were drawn as micro-pipettes from Clarck Medical capillairy glass tubes (outer diameter $3.0 \mathrm{~mm}$, type: GC200-15), with a tip diameter of approximately $50 \mu \mathrm{m}$ at the base of the tip and $\mathrm{I}-2 \mu \mathrm{m}$ at the end of the tip, the tip diameter thus conically declined over a length of approximately $5 \mathrm{~mm}$. After drawing, the micro-pipettes were bent in a $Z$ like manner (Fig. 1.), in order to avoid a nonhorizontal working plane of the transducer and length displacement instrument.

Cells were attached between a fixed micro-pipette mounted to a Märzhauser three-dimensional electromechanical micromanipulator (type STM 3), fixed onto the microscope object table, and a similar pipette connected to an opto-mechanical micro force transducer, developed in our own laboratory, with a sensitivity of $10 \mu \mathrm{N} \mathrm{V}^{-1}$, a linear range of $\pm 140 \mu \mathrm{N}$, a resolution better than $0.1 \mu \mathrm{N}$ and a long term drift of approximately $2 \mu \mathrm{N} \mathrm{h}^{-1}$ (Glerum \& Van Mastrigt, 1990). This transducer was mounted on a specially designed vertical movement stage connected directly to the side of the cell incubator. Figure I shows a cross-section through the central parts of the measurement apparatus.

Prior to the attachment procedure the tips of the micropipettes were coated by dipping them for $5 \mathrm{~min}$ in a $0.1 \mathrm{mg} \mathrm{ml}^{-1}$ solution of Poly-L-Lysine (mol. weigth 100000 , Sigma, P 1274), and subsequent rinsing for a few seconds in destilled water.

The smooth muscle cell selected by means of the fluorescence technique was first, at one of its ends, approached by the

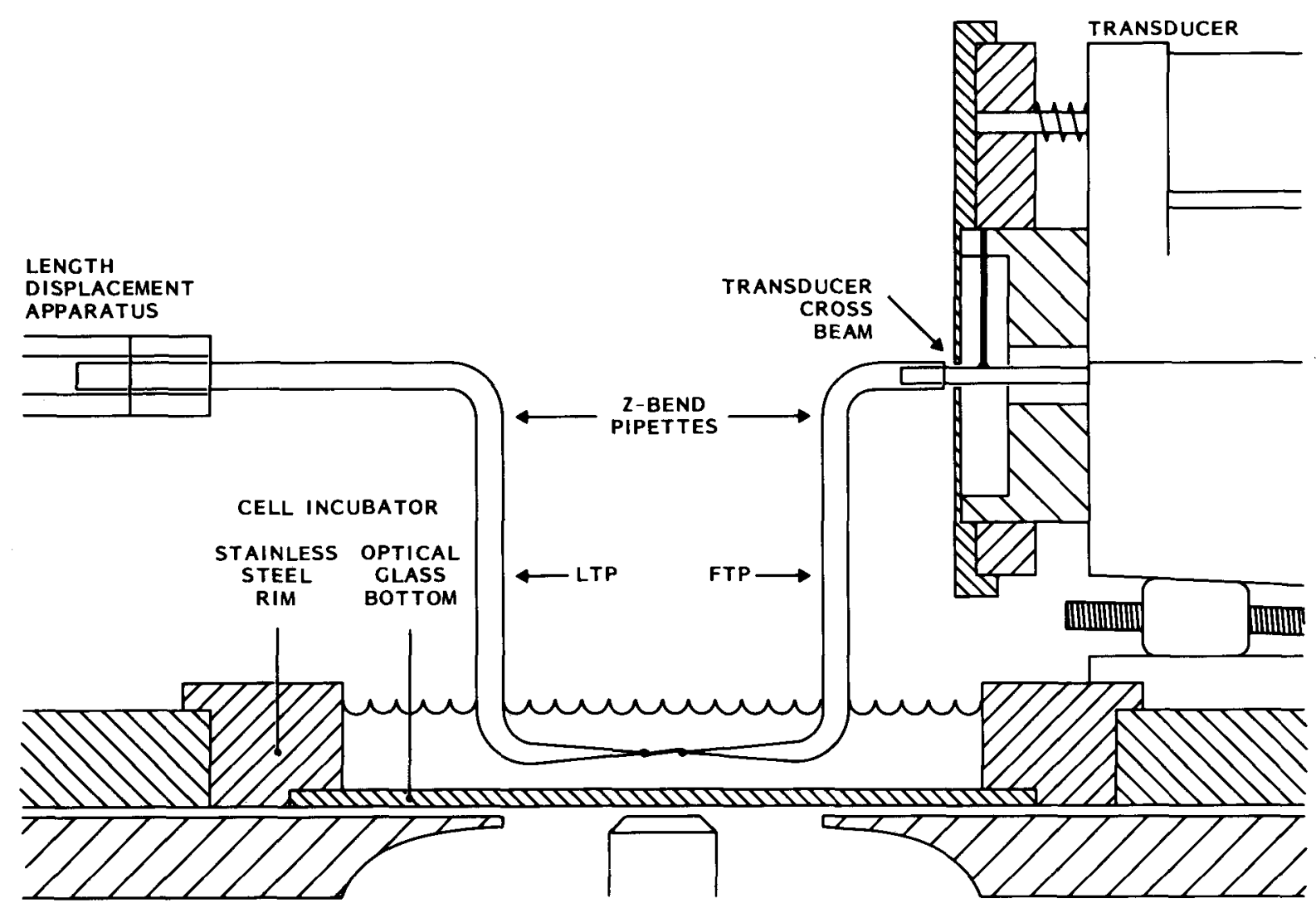

Fig. 1. Cross-section of the cell measurement apparatus. The cell is attached between two Z-bend micro-pipettes. The right pipette (FTP) is connected to an ultrasensitive force transducer, the left pipette (LTP) is connected to a length displacement apparatus. The cell is submerged in a temperature controlled cell incubator mounted on an inverted microscope. 
tip of the micro-pipette mounted in the three-dimensional (left hand) micromanipulator. As soon as the tip met the cell, the cell would be attracted to the tip by static force. This binding was strong enough to lift the cell from the bottom of the incubator and bring it to the tip of the pipette attached to the transducer, which was brought into focus in the right part of the field of vision. At this point the right hand end of the cell was laid just under the tip of the transducer pipette and next this tip was lowered onto the cell by means of the transducer's elevation control. This was done in such a way that the cell was clamped between the tip and the bottom of the incubator. Next, the left hand end of the cell was brought alongside the transducer pipette (Fig. 2.1) and the first part of the knot was made by bringing the left hand manipulator clockwise over the transducer pipette (Fig. 2.2). To be able to complete the turn the transducer pipette was carefully elevated and the left hand pipette was successively turned clockwise underneath (Fig. 2.3) and again over the transducer pipette (Fig. 2.4). Next, another half clockwise turn was made by bringing the left hand pipette underneath and aside the transducer pipette again (Fig. 2.5). From this position the knot was tightened by carefully pulling the left hand manipulator to the left, thus stretching the cell between the two micro-pipettes until the first minimal rise in tension (approximately $\mathrm{I}-2 \mu \mathrm{N}$ ) was observed (Fig. 2.5-2.7).

The cell was brought to its 'resting length' by applying one or more length steps of $10 \mu \mathrm{m}$. Resting length was defined as the free length between the knots that was optically measured through the microscope after the first length step of $10 \mu \mathrm{m}$ that gave rise to a measureable tension increment directly followed by a visco-elastic relaxation.

In order to perform rampwise stretches on a single smooth muscle cell with the Märzhauser three-dimensional micromanipulator, its $X$-axis electronic control was modified to allow unidirectional pulse control by either an external timer or a

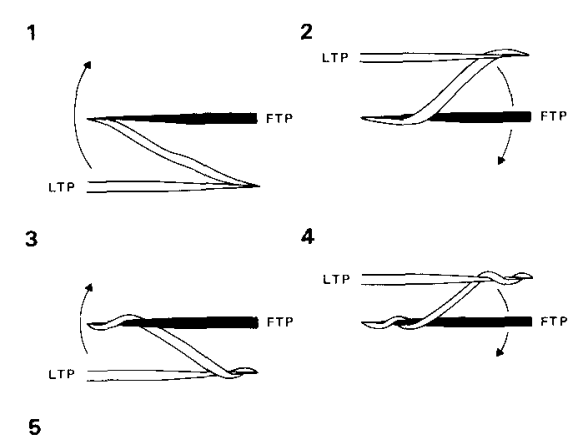

5

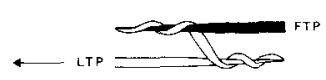

6
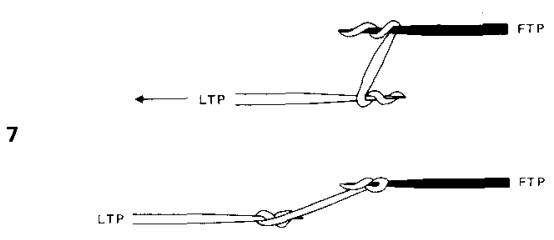

Fig. 2. Schematic representation of the knotting procedure used for attaching isolated mammalian single smooth muscle cells to two axially aligned micropipettes. See explanation of procedure in text. computer, both via a TTL input. Velocity during the selected ramp duration could be adjusted by changing the motor drive voltage with a calibrated ten turn potentiometer. During all experiments ramp duration was kept at $0.2 \mathrm{~s}$ and velocity at $50 \mu \mathrm{m} \mathrm{s}^{-1}$, resulting in length steps of $10 \mu \mathrm{m}$.

Reliablility of the knotting technique was investigated by repeatedly stretching (at 15 min intervals) the cell by length increments of $10 \mu \mathrm{m}$, resulting in a number of force steps, directly followed by stress relaxation. Force steps and relaxation curves were stored online in a PDP 11 type computer and analysed to evaluate the cell attachment technique. Part of the analysis consisted of calculation and subsequent plotting of the force increment at the moment of the ramp stretch $(\mathrm{dF})$, (Figs $4 \mathrm{~A}, \mathrm{~B}$ ), as a function of length. Three aspects of the stability of the knots were investigated: (1) whether the knots would hold or not at the moment of initial straining up to resting length; (2) whether the cell would break at/after the ultimate stretch ramp was applied or one of the knots would untie; (3) whether after any stretch ramp a decline in the amount of force increment $(\mathrm{dF})$ had occurred and if so, whether these declines happened just before breakage of the cell, or in the middle of a series of stretch ramps.

\section{Results}

In a total of 17 experiments 11 pig urinary bladder smooth muscle cells and 6 smooth muscle cells from human a terme pregnant uteruses were successfully attached and the quality of attachment was investigated.

Tables 1 and 2 show: (1) that in all cells the knots initially tightened correctly, as initial relaxation at 'resting length' could be attained; (2) that in all cells the strength of the attachment exceeded the force level necessary to break the cell, as all tested cells ultimately broke; (3) the total number of ramp stretches that could be applied to the cell, starting from rest length, including the ramp at which the cell broke; (4) the number of times a decline of force increment (dF) occurred per cell; (5) how many ramps could still be applied after the first decline of $\mathrm{dF}$ had occurred, including the ramp at which the cell ultimately broke.

Figure 3 shows an example of the force response resulting from application of a length ramp, figure $4 \mathrm{~A}$ shows the $\mathrm{dF}$ length diagram of a bladder smooth muscle cell, without intermittent decrease in $\mathrm{dF}$ occurring. Figure $4 \mathrm{~B}$ shows a cell displaying repeated decreases of $\mathrm{dF}$, still ultimately leading to cell breakage.

\section{Discussion}

Four methods for attaching cells to measurement devices have been published: (1) Clamping seems to be the worst solution, inevitably leading to the two cell ends being clamped to a non-moving underlayer, which means indirect measurement of shortening or force on a somehow folded cell. Van Dijk and co-workers (1984) pointed out that with their clamping method slipping occurred at approximately $1.5 \mu \mathrm{N}$, probably long before maximum force was reached. These force levels are surpassed with a 
Table 1. Pig urinary bladder smooth muscle cells; table shows in column (1) whether knots tightened correctly $(+$ or -$)$, column (2) whether the cell ultimately broke or not $(+$ or - ), column (3) the number of ramp stretches that could be applied to the cell, starting from rest length including the ramp at which the cell ultimately broke (n), column (4) the number of times a decline of force increment $(\mathrm{dF}$ ) occurred per cell (n), and column (5) the number of ramp stretches that could still be applied, including the ultimate ramp at which the cell broke, after the first/last decline of $\mathrm{dF}$ had occurred $(\mathrm{n} / \mathrm{n}) .^{*}=$ Standard Error of the Mean.

\begin{tabular}{|c|c|c|c|c|c|}
\hline cell no & $\begin{array}{l}\text { initial } \\
\text { knot } \\
\text { tight } \\
+1-\end{array}$ & $\begin{array}{c}\text { ultimate } \\
\text { breakage } \\
+1-\end{array}$ & $\begin{array}{l}\text { number of } \\
\text { ramp } \\
\text { stretches } \\
\text { applied } \\
\quad(\mathrm{n})\end{array}$ & $\begin{array}{l}\text { number of } \\
\text { declines } \\
\text { of } d F \\
\quad(n)\end{array}$ & $\begin{array}{l}\text { number of } \\
\text { ramps after } \\
\text { first/last } \\
\text { decline of } d F \\
(\mathrm{n} / \mathrm{n})\end{array}$ \\
\hline 1 & + & + & 10 & 1 & 1 \\
\hline 2 & + & + & 7 & $I$ & I \\
\hline 3 & + & + & 8 & $I$ & 1 \\
\hline 4 & + & + & 11 & 3 & $7 / 1$ \\
\hline 5 & + & + & 13 & $I$ & 2 \\
\hline 6 & + & + & 14 & 5 & $7 / 0$ \\
\hline 7 & + & + & 10 & 2 & $3 / 1$ \\
\hline 8 & + & + & 10 & 1 & 3 \\
\hline 9 & + & + & 5 & 1 & $I$ \\
\hline 10 & + & + & 5 & 1 & 2 \\
\hline 11 & + & + & 7 & 1 & 2 \\
\hline average & $-\cdot-$ & $-\cdot-$ & 9.1 & 1.64 & 2.72 \\
\hline S.E.M.* & & & 0.90 & 0.39 & 0.68 \\
\hline
\end{tabular}

factor of thirty in our material. Also the pressure excerted on the cell by the micro-pipette tips used in this technique, might evoke depolarisation and/or contraction of the cell. (2) Vacuum attachment gives rise to the problem of transferring the vacuum to the right spot, without compromising transducer stability and compliance. Any tube or hose crossing to the active tip of a longitudinally working transducer to obtain vacuum at its end will influence the transducer's properties and stability, whereas working with a fixed base of the vacuum micro-pipettes attached to the cell ends leaves one with the opportunity to measure the bending of the tip in only one way or

Table 2. Human pregnant a terme uterus smooth muscle cells; table shows in column (1) whether the knots tightened correctly $(+$ or -$)$, column $(2)$ whether the cell ultimately broke or not $(+$ or -$)$, column (3) the number of ramp stretches that could be applied to the cell, starting from rest length including the ramp at which the cell ultimately broke $(n)$, column (4) the number of times a decline of force increment $(\mathrm{dF})$ occurred per cell $(\mathrm{n})$, and column (5) the number of ramp stretches that could still be applied, including the ultimate ramp at which the cell broke, after the first/last decline of $d F$ had occurred $(n / n)$. * = Standard Error of the Mean.

\begin{tabular}{|c|c|c|c|c|c|}
\hline cell no & $\begin{array}{l}\text { initial } \\
\text { knot } \\
\text { tight } \\
+1-\end{array}$ & $\begin{array}{c}\text { ultimate } \\
\text { breakage } \\
+1-\end{array}$ & $\begin{array}{l}\text { number of } \\
\text { ramp } \\
\text { stretches } \\
\text { applied } \\
\quad(\mathrm{n})\end{array}$ & $\begin{array}{l}\text { number of } \\
\text { declines } \\
\text { of } d F \\
\text { (n) }\end{array}$ & $\begin{array}{l}\text { number of } \\
\text { ramps after } \\
\text { first/last } \\
\text { decline of } d F \\
(\mathrm{n} / \mathrm{n})\end{array}$ \\
\hline 1 & + & + & 11 & 1 & 1 \\
\hline 2 & + & + & 7 & 1 & 0 \\
\hline 3 & + & + & 14 & 2 & $6 / 0$ \\
\hline 4 & + & + & 19 & 2 & $7 / 1$ \\
\hline 5 & + & + & 8 & 1 & 3 \\
\hline 6 & + & + & 10 & 1 & 1 \\
\hline average & $-\cdot-$ & $-\cdot-$ & 11.5 & 1.33 & 3.00 \\
\hline S.E.M. ${ }^{*}$ & & & 1.80 & 0.21 & 1.18 \\
\hline
\end{tabular}




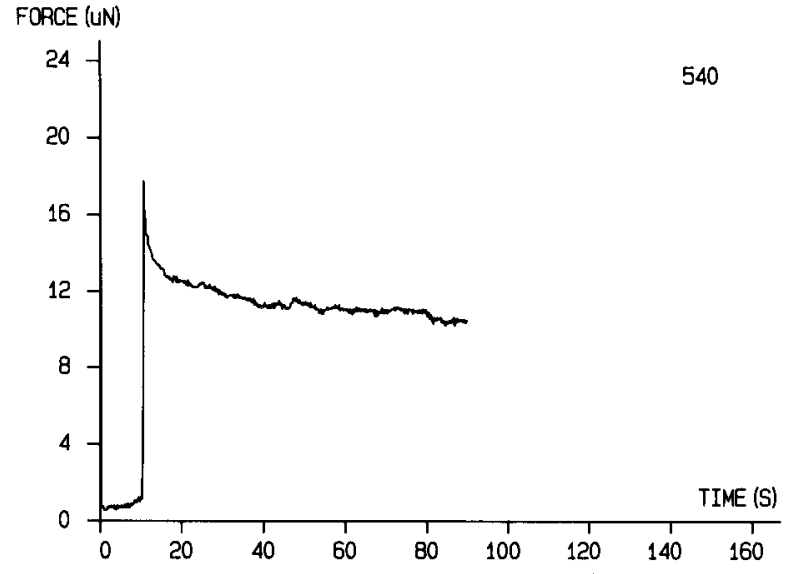

Fig. 3. An example of the force response resulting from application of a rampwise increment in length of an attached smooth muscle cell.

another, leading to inaccuracies and longterm instability (Ishii, 1988, personal communication) in the case of optoelectrical position detection, or, if the position detection is done by means of a video system, to a very low band width (Wieringa et al., 1984).

Clamping neither vacuum attachment seem very attractive in view of the axial contractile and passive forces that are to be measured accurately, and require the introduction of various kinds of correction factors dealing with folding of the cell (Van Dijk., 1984), or cell to probe contact surface, (Tung, 1986), whereas the relatively sharp bends in the cell in Ishii's method (Ishii et al., 1988) might cause other kinds of artefacts (e.g. premature depolarisation). (3) Cell glueing seems, theoretically, to be the most attractive method of cell attachment and even seems to be a sine qua non for cells other than smooth muscle cells (Copelas et al., 1987). Of the few bio-compatible glues available, fibrin glue seems very promising, but in our limited experience it proved to be a very viscose fluid,

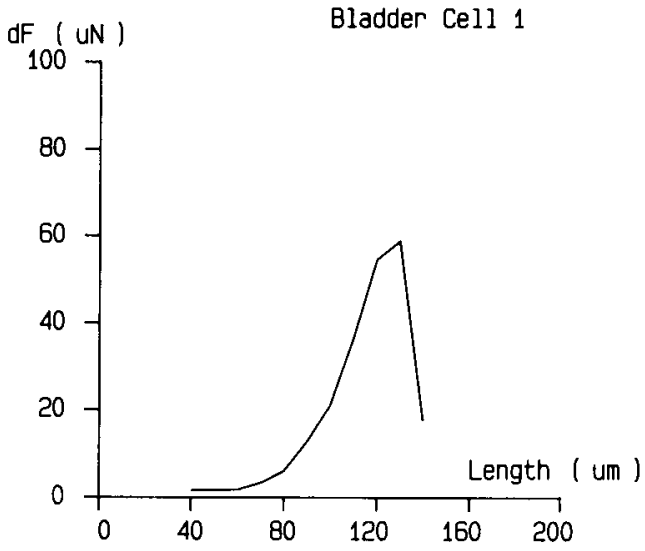

Fig. 4A. A typical example of the force increment $(\mathrm{dF})$ resulting from a rampwise stretch of constant amplitude $(10 \mu \mathrm{m})$ as a function of cell length, showing only a final discontinuity. rather difficult to apply and control at the desired microscopic scale. A few pilot experiments (Glerum, unpublished results), testing fibrin glue threads between micro-pipettes, showed results in accordance to Copelas (1987). (4) Cell knotting has for a decade or so proven to be a reliable method of cell attachment (Fay, 1977, Warshaw \& Fay, 1983). The method has two principal prerequisites, a primary attachment procedure (static attraction between opposite charges) and cells that are long enough to permit the multiple knots (amphibian stomach cells, L > $150 \mu \mathrm{m}$ ). If these conditions are met a stable attachment can be made, with an axial pull on the cell, without sharp bends at the cell ends.

The alternative knotting technique for shorter cells, as presented in this paper, involving a single knot and primary attachment to micro-pipettes without anion exchange resin beads, but with a coating of Poly-L-Lysine, shows very good stability and realiability of the knots obtained. All knots proved to be stronger than the cells themselves, as the cells broke or tore apart without any of the knots loosening.

The present technique was developed as a modification of the originally published technique (Warshaw \& Fay, 1983), for the following reasons: (1) Glueing anion exchange resin beads to the micro-pipette tips was very time consuming, with a moderate to very low success rate, depending on the type of glue used. Even if successful, it seldom resulted in a stable binding resistant to salt water and activating bases and acids. (2) In those cases where reliably glued, activated beads had been obtained we found that either cells would not attach to the beads (which might have been a matter of cell vitality) or that even when a cell attached to one bead, it would seldom attach to a second bead (possibly because the charges of both beads interacted at the shorter distance due to the use of short cells). (3) In the few cases in which we succeeded to tie an inital knot we experienced that passing around the resin beads took up an unacceptable part of the cell's length.

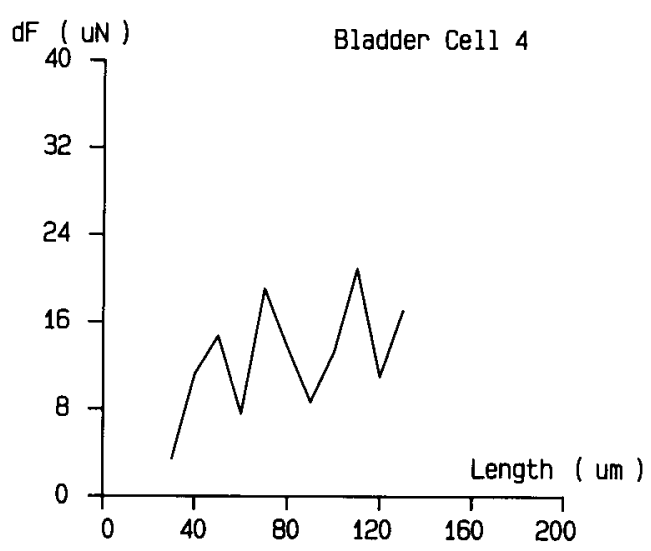

Fig. 4B. An example of the force increment $(\mathrm{dF})^{\circ}$ resulting from a rampwise stretch of constant amplitude $(10 \mu \mathrm{m})$ as a function of cell length, showing repeated discontinuities. 
The method presented is also based upon attraction between oppositely charged surfaces, but the charge on the micro-tools is no longer concentrated in a hindering bead, but spread out over the surface of the micro-tool tips. In this way a smaller circumference has to be covered by the cell in making the turns for the knotting procedure and thus shorter cells can be measured. This also leads to a larger surface of statical attraction and contact between cell and micro-tool, thus increasing friction, and therefore enabling single knots which permit the investigation of shorter cells.

As the negative surface charge of the cell, which depends on the cell's metabolic processes, is crucial for the first attachment, only vital cells, showing a functional internal metabolism will demonstrate sufficient adherence to the coated micro-tips. It is therefore necessary to use an in vitro vitality test to select the best cells available. Only techniques that test for cytosol enzyme activity, such as FDA., or mitochondrial enzyme activity, such as Rhodamine 123, will yield proper information, whereas the Trypan Blue exclusion test proved insufficient (Glerum et al., 1987). During the experiments it was observed that vital cells showed a double refracting cell membrane under phase contrast microscopy, so enabling limited cell selection without vital staining techniques.

The initial turn of the knot, before the cell overcrosses itself, is only possible because of friction between the cell and the micro-pipettes as a result of static attraction, so antagonising the rotatory pull on the cell while turning the knot. The larger the static attraction, the larger the normal force acting perpendicularly in the contact zone between cell and micro-tip, so enhancing friction. Also the longer the contact zone, due to the fact that the whole pipette tip is coated and thus stabilises the first knot turn over its entire circumference, the larger the resulting friction will be, making the tying of the knots easier. Once the cell body has crossed over itself, the normal force will increase due to the self bracing mechanism that is introduced in this way and the knots will tighten to such an extent that longitudinal pull is possible, even though the micro-tips become smaller in diameter towards the end.

The use of Poly-L-Lysine for cell attachment has been reported before (Tarr et al., 1979), for attaching isolated cardiac myocytes with (contractile) forces not exceeding $1 \mu \mathrm{N}$. With our technique forces as high as $160 \mu \mathrm{N}$ have been recorded without malfunction of the attachment.

The decreases in increment of $\mathrm{dF}$ seen in the majority of the $\mathrm{dF}$ vs length diagrams might be due to slipping of one or both knots. The $\mathrm{dF}$ decreases occurring halfway through the stretching cycle are especially suspect for knot slipping. As tables 1 and 2 show, most of the 'slips' occurred just prior to the breaking of the cell. If more than one 'slip' occurred, there was always, after a number of non 'slipping' ramp stretches, a final 'slipping' ramp stretch just prior to, or at the moment of, cell breakage, possibly indicating that it is not the knot stability that gives rise to the 'slip' phenomenon, but the yielding of an internal mechanism. This will be further discussed in part 3 of this publication.

It is concluded that our method of smooth muscle cell attachment is simple to perform and enables optimal longitudinal force measurements on such cells, with a minimal length of approximately $80 \mu \mathrm{m}$.

\section{References}

COPELAS, L., BRIGGS, M., GROSSMAN, W. \& MORGAN, J. P. (1987) A method for recording isometric tension development by isolated cardiac myocytes: transducer attachment with fibrin glue. Pflugers Arch. 408, 315-17.

DIJK, A. M. VAN, WIERINGA, P. A., MEER, M. VAN DER \& LAIRD, J. D. (1984) Mechanics of resting isolated single vascular smooth muscle cells from bovine coronary artery. Am. J. Physiol. 246, (Cell Physiol. 15), C277-87.

FAY, F. S., COOKE, P. H. \& CANADY, P. G. (1976) Contractile properties of smooth muscle cells. In Physiology of Smooth Muscle (edited by BUlBRING, E. and SHUBA, M. F.), pp. 249-64. New York: Raven Press.

FAY, F. S. (1977) Isometric contractile properties of single isolated smooth muscle cells. Nature, Lond. 265, 553-6.

GLERUM, I. J., MASTRIGT, R. VAN, ROMIN, J. C. \& GRIFFITHS, D. J. (1987) Isolation and individual electrical stimulation of single smooth muscle cells from the urinary bladder of the pig. J. Musc. Res. Cell Mot. 8, 125-34.

GLERUM, J. J. \& MASTRIGT, R. VAN (1990) Mechanical properties of mammalian single smooth muscle cells, part I: A low cost large range microforce transducer. J. Musc. Res. Cell Motil. 11, 33I-7.

ISHII, N. \& TAKAHASHI, K. (1982) Length-tension relation of single smooth muscle cells isolated from the pedal retractor muscle of Mytilus edulis. J. Musc. Res. Cell Mot. $3,25-38$.

ISHII, N. (1988) Personal communication, Symposium on Smooth Muscle, Cardiothoracic Institute, London.

ISHII, N., SIMPSON, A. W. M. \& ASHLEY, C. C. (1988) Intracellular free calcium $\left(\left[\mathrm{Ca}^{2+}\right]_{\mathrm{i}}\right)$ and the 'catch' contraction in isolated molluscan smooth-muscle (ABRM) cells. (abstract) J. Musc. Res. Cell Motil. 9, 463.

TARR, M., TRANK, J. W., LEIFFER, P. \& SHEPHERD, N. (1979) Sarcomere length-resting tension relation in single frog atrial cardiac cells. Circ. Res. 45, 554-9.

TUNG, L. (1986) An ultrasensitive transducer for measurement of isometric contractile force from single heart cells. Pflügers Arch. 407, 109-15.

WARSHAW, D. M. \& FAY, F. S. (1983) Cross-bridge elasticity in single smooth muscle cells. J. Gen. Physiol. 82, 157-99.

WIERINGA, P. A., MEER, M. VAN DER, DIJK, A. M. VAN \& LAIRD, J. D. (1984) Sensitive force transducer system for mechanical studies of single isolated vascular smooth muscle cells. Med. \& Biol. Eng. \& Comput. 22, 130-7. 